\title{
ELEMENTARY SCHOOL TEACHERS' EXPERIENCES REGARDING THE PREREFERRAL PROCESS
}

\author{
Mine Kizir ${ }^{1}$, \\ Candan Hasret Şahin ${ }^{2 i}$ \\ $\mathrm{PhD}$, Muğla Sıtkı Koçman University, \\ Faculty of Education, \\ Turkey
}

\begin{abstract}
:
Informing teachers about identifying students at risk is necessary and important for effective application of interventions in the pre-referral process. The purpose of this study was to determine the adaptations that elementary school teachers did for their students at risk in the pre-referral process and to determine these teachers' experiences in the process. In this study, the phenomenological design was used to determine the elementary school teachers' views about the pre-referral process and their experiences regarding the process. In the present study, which was conducted to determine elementary school teachers' experiences and views about the pre-referral process, three themes were obtained as a result of the analysis of the data collected via the interviews. The themes were as follows: teachers' experiences and views about the identification phase, instructional adaptations in the pre-referral process and overall thoughts and suggestions regarding the pre-referral process. Informing teachers about the pre-referral process and about what to do in this process will not only help decrease the number of students involved in referral process by increasing the in-class adaptations but also allow keeping the students in the same class who will be able to continue their education with their peers with help of in-class interventions.
\end{abstract}

Keywords: pre-referral process, elementary school teacher, student at risk, experiences

\section{Introduction}

Assessment is an essential element for the planning and execution of the teaching process in educational environments. Assessment is the process of obtaining information about students' educational needs and about the necessary educational decisions to be taken within the scope of the curriculum (Salvia, Ysseldyke and Bolt, 2010; Gürsel and Vuran, 2015). The educational needs of all students differ depending on their individual

iCorrespondence: email candansahin@mu.edu.tr 
differences. These varying educational needs make it necessary to do certain adaptations and arrangements in the teaching process. Therefore, the process of educational assessment is of great importance for determining the needs of every student regarding the teaching process. In the Special Education Services Regulations published by the Ministry of National Education (MoNE) in 2018, the term is defined as the process of educational assessment and diagnosis and as determining individuals' performances and needs in the area of individual development and in academic fields. The educational assessment process includes steps that should be planned and implemented attentively (Figure 1).

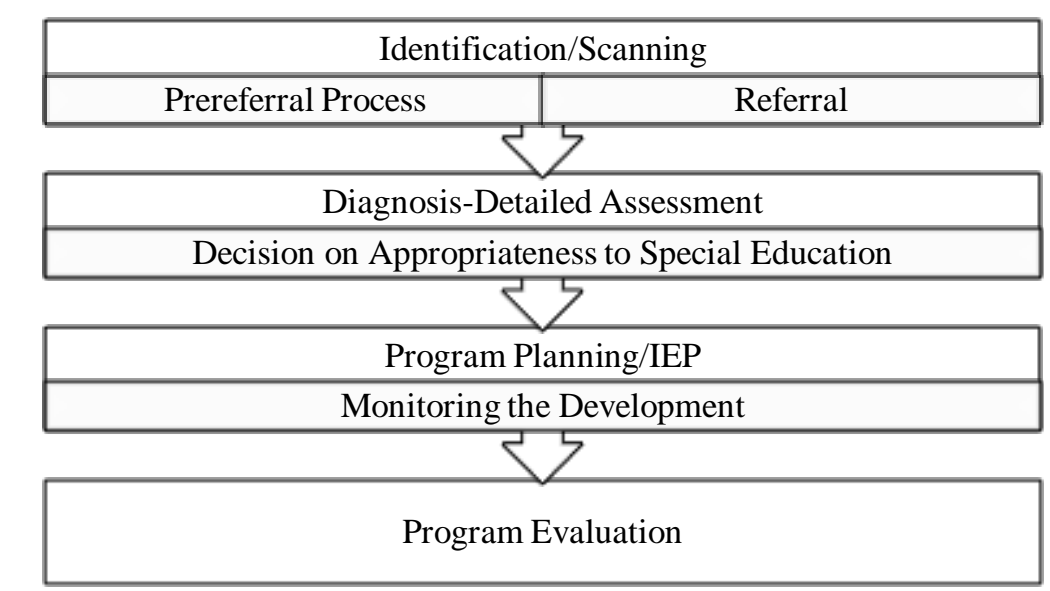

Figure 1: Steps Followed in the Educational Assessment Process

(Gürsel and Vuran, 2015)

The purpose of the educational assessment process is to determine the needs of students who experience problems in the education process and to provide these students with the opportunity to receive special education services if necessary (Cuhadar, 2017). Each step of the educational assessment process is important. However, the initial identification phase is of great importance in terms of focusing on all the students in traditional classrooms and identifying the students at risk (Noll, Kamps and Seaborn, 1993; Sindelar, Griffin, Smith and Watanabe, 1992). Following the initial process of identifying the students who are considered to be in the risk group, the pre-referral process begins (Hammond and Ingalls, 1999).

In the pre-referral process, by doing arrangements in the educational environments and doing interventions in class before detailed assessment (Fuchs et.al., 1990), the purpose is to provide students in the risk group with the opportunity to continue their education with their peers (Carter and Sugai, 1989; Good, 2004; Noll, Kamps and Seaborn, 1993; Sindelar et al., 1992). The teacher's correct and effective interventions in class in the pre-referral process increase students' learning, decrease their behavioural problems, encourage in-class participation (Sindelar et al., 1992) and prevent many students from being labelled (Will 1986; Carter and Sugai, 1989). Reynolds and Balow (1972) point out that incorrect diagnosis may lead to such consequences as discrimination and being labelled. 
In order for the pre-referral process to function well, the process should be planned and executed by a team formed of the school staff. For such teams, the prereferral process refers to an intervention process (a) which is preventive (Fuchs et.al., 1990; Garcia and Ortiz, 2006), (b) which focuses on problem solving (Noll, Kamps and Seaborn, 1993), (c) which adopts an action cycle and (d) which aims to increase the success of teachers and students in traditional educational environments (Buck, Polloway, SmithThomas and Cook, 2003; Jennings, 2008). The pre-referral process, which is regarded as an alternative model before diagnosis (Graden, Casey and Christenson, 1985; Graden, Gasey and Bonstrom, 1983; Laverty, 2007) and as a recommended model (Carter and Sugai, 1989), includes in-class interventions and precautions. Development, application and evaluation of the intervention plan for the pre-referral process require teamwork and cooperation (Yetter, 2010).

When international studies on the pre-referral process are examined, it is seen that teams with different names such as child research team, teacher support team and prereferral support team are formed at schools (Buck et al., 2003; Yetter, 2010). The prereferral process is conducted successfully at schools where these teams have been formed (Hammond and Ingalls, 1999), and the process is considered to be effective in decreasing the number of the children diagnosed (Garcia and Ortiz, 2006; Noll, Kamps and Seaborn, 1993; Safran and Safran, 1996; Safran and Safran, 1997; Sindelar et al., 1992). In related literature, there are a wide variety of studies focusing on defining the pre-referral process and teams (Graden, Casey and Christenson, 1985; Graden, 1989; Pugach and Johnson, 1989; Safran and Safran, 1997), development of a measurement tool (Yetter, 2010), function and effectiveness of pre-referral teams (Young and Gaughan, 2010), practical differences between cities (Buck et.al., 2003; Carter and Sugai, 1989; Turnbull, 2019), prereferral process practices for children with emotional and behavioral disorders (Noll, Kamps and Seaborn, 1993; Del'Holme, Kasari, Forness and Bigley, 1996) and practices for groups with different ethnicities (Garcia and Ortiz, 2006; Henderson, 2008). In addition, there are a number of studies conducted to investigate the teachers' pre-referral process and their practices in this process (For example; Lane, Pierson, Robertson and Little, 2004; Lane, Mahdavi and Borthwick-Duffy, 2003; Lhospital and Gregory, 2009; Newell, 2018; Slonski-Fowler and Truscott, 2004; Swank, 2017; Tunc, 2011). Moreover, these studies examined teachers' perceptions regarding the pre-referral process and practices (Lane, Mahdavi and Borthwick-Duffy, 2003; Lee-Tarver, 2006; Slonski-Fowler and Truscott, 2004; Swank, 2017) , their views (Cuhadar, 2017; Lane, Pierson, Robertson and Little, 2004; Tunç, 2011), the changes in teachers' levels of stress after participation in a team (Lhospital and Gregory, 2009) and the relationship between teacher efficacy and students' referral to the intervention support team (Newell, 2018).

Though regarded as an effective application (Buck et al., 2003; Young and Gaughan, 2010), referral of students by the teacher directly to the diagnosis process without doing any assessment or in-class interventions because these students differ from their peers in terms of their learning characteristics and behaviours or because they are in the risk group (Carter and Sugai, 1989; Ysseldyke, Vanderwood and Shriner, 1997) is considered to be a prevalently favoured approach (Graden, Gasey and Bonstrom, 1983; 
Kargin, 2007; Young and Gaughan, 2010).Based on this approach, elementary school teachers can refer the student to the diagnosis process without initiating any intervention process (Graden, Gasey and Bonstrom, 1983). Before the referral, it is necessary to collect data systematically for the assessment of students and to prepare a written intervention plan including the instructional adaptations (Sindelar et al., 1992; Young and Gaughan, 2010). In one study, Çuhadar (2017) states that teachers do not experience any problems in the initial identification phase and that they do not continue systematically in the referral process, though. Referrals without any assessment or a written report point to the increase in the number of students diagnosed (Young and Gaughan, 2010) and thus to the related precautions to be taken. In our country, it is seen that the number of studies on the pre-referral process is limited (Tunc, 2011); that there is no governmental obligation to form pre-referral teams and that the documents sent before diagnosis by teachers to the Guidance and Research Centre (GRC) includes an intervention plan or the results of the implementation of the intervention plan (Bozkurt, 2009).Systematic interventions before the pre-referral process demonstrate that the number of applicant students will decrease (Hammond and Ingalls, 1999; Noll, Kamps and Seaborn, 1993; Young and Gaughan, 2010; Weishaar, Weishaar and Budt, 2002), and it could be stated that in our country, no systematic interventions are done for students found in the risk group. Without doubt, the key role in the development and implementation of interventions, or before the referral, belongs to teachers (Carter and Sugai, 1989; Dunn, 2006). Determining teachers' views will not only help overcome the problems experienced in the pre-referral process but also contribute to the development of a model beneficial for the problems.

In the present study, the purpose was to determine the adaptations that elementary school teachers did for their students at risk in the pre-referral process and to determine these teachers' experiences in the process. In line with this purpose, the following research questions were directed in the study:

- What are teachers' experiences in the initial phase of identifying the students at risk in terms of special needs in class?

- What are instructional adaptations that teachers do in the pre-referral process?

- What are teachers' experiences in the phase of referral to the detailed assessment?

\section{Methods}

\subsection{Research Model}

In this study, the phenomenological design, one of qualitative research designs, was used to determine the elementary school teachers' views about the pre-referral process and their experiences regarding the process. The phenomenological design aims "to reveal individuals' experiences and perceptions regarding a phenomenon and the meanings they attribute to that phenomenon"(Y1ldirım and Simsek, 2008), and in line with this purpose, the research data are collected, analyzed and interpreted. 


\subsection{Participants}

While determining the participants in the study, the method of "criterion sampling" was applied. This method is a purposeful sampling method, which in the planning phase of the study, allows determining the criteria for participants who will serve the purpose of the study (Yıldırım and Simsek, 2008). Accordingly, the first criterion was that the participants should be from the department of Elementary School Teaching. Another criterion was that during their professional lives, the teachers should refer at least one student for diagnosis to GRC. In other words, they were expected to have individually experienced the pre-referral process. The last criterion was that they should volunteer to take part in the study. After the researchers determined the criteria for teachers to participate in the study, 15 elementary school teachers were interviewed. Table 1 presents information about the teachers participating in the study.

Table 1: Information about the participants

\begin{tabular}{|c|c|c|c|c|}
\hline Participant & Gender & Age & Professional Experience & Diagnosis Group \\
\hline P1 & F & 40 & 18 years & Intellectual Disability \\
\hline P2 & F & 56 & 34 years & Language and Speech Disorder \\
\hline P3 & F & 54 & 33 years & $\begin{array}{c}\text { Intellectual Disability } \\
\text { Learning Disability } \\
\text { Being Gifted }\end{array}$ \\
\hline P4 & M & 32 & 10 years & Learning Disability \\
\hline P5 & F & 50 & 30 years & $\begin{array}{c}\text { Intellectual Disability } \\
\text { Learning Disability }\end{array}$ \\
\hline P6 & F & 32 & 8 years & Learning Disability \\
\hline P7 & F & 48 & 32 years & Unknown \\
\hline P8 & F & 50 & 23 years & $\begin{array}{c}\text { Attention Deficit and } \\
\text { Hyperactivity Disorder }\end{array}$ \\
\hline P9 & F & 44 & 21 years & $\begin{array}{c}\text { Intellectual Disability } \\
\text { Learning Disability } \\
\text { Emotional Behaviour Disorder }\end{array}$ \\
\hline P10 & M & 47 & 25 years & Intellectual Disability \\
\hline P11 & F & 26 & 5 years & $\begin{array}{c}\text { Intellectual Disability } \\
\text { Language and Speech Disorder }\end{array}$ \\
\hline P12 & F & 44 & 20 years & Learning Disability \\
\hline P13 & F & 29 & 4 years & Intellectual Disability \\
\hline P14 & F & 54 & 31 years & Intellectual Disability \\
\hline P15 & F & 33 & 11 years & \\
\hline
\end{tabular}

\subsection{Data Collection Tool and Data Collection}

In the study, as the data collection technique, semi-structured interviews were held with the elementary school teachers to determine their views about the pre-referral process. In the process of determining the interview questions, first, the related literature was reviewed. Accordingly, the initial form of the interview questions was prepared by the first author. Following this, the two authors discussed these questions and decided on the final form of the questions. Consequently, a total of 14 questions were prepared in 
relation to the identification phase of the teachers, the instructional adaptations in the pre-referral process and the overall process of the pre-referral.

The interviews were held by the first author at the teachers' schools or on the phone between 21 November 2019 and 09 January 2020.In order to make the participants comfortable, the participants were allowed to choose either to be interviewed on face-toface basis or on the phone out of their office/working hours. As a result, nine participants were interviewed on the phone, and six participants were interviewed on face-to-face basis. The interviews lasted 9 minutes 20 seconds at shortest and 32 minutes 33 seconds at longest making 4 hours 33 minutes 4 seconds in total.

\subsection{Data Analysis}

In the data analysis process, the research data were analyzed and interpreted using the method of descriptive analysis in accordance with the themes obtained in relation to the research questions. In order to audio-record the interviews, the participants were asked for their verbal consents in advance. The participants in the audio records were coded as $\mathrm{P} 1, \mathrm{P} 2 \ldots$ as required by ethical principles. All the interviews were first transcribed and read repeatedly for a few times by the first author, and for each theme, related categories and sub-categories were formed. In the first phase, after the interpretation of all the data, a total of 15 categories and 89 sub-categories were obtained under three themes. In this process, both authors discussed and agreed on the themes, categories and sub-categories. Consequently, among all the sub-categories, those similar to each other were combined, and a total of 51 sub-categories were obtained.

\subsection{Credibility, Transferability and Confirmability}

The necessary applications were carried out for the credibility, transferability and confirmability of the study as follows. In terms of "interrater reliability" examined for confirmability in the study, one expert from the field of special education and the first author read the interviews of four participants (corresponding to about $30 \%$ of all the interviews) in accordance with the category key formed, and the expert and the first author evaluated these four interviews independently of each other. The result was calculated by using the formula of [(Agreement / Agreement + Disagreement) x 100] suggested by Miles and Huberman (1994), and the agreement rate between the raters was 95\%. In terms of transferability, "purposeful sampling" was applied, and direct quotations from the interviews held with the participants were used. In addition, for credibility, one of the participants, P13, was requested to read the written transcriptions of the interview and asked whether s/he confirmed his/her statements in the interview.

\section{Results}

In the present study, which was conducted to determine elementary school teachers' experiences and views about the pre-referral process, three themes were obtained as a result of the analysis of the data collected via the interviews. The themes were as follows: teachers' experiences and views about the identification phase, instructional adaptations 
in the pre-referral process and overall thoughts and suggestions regarding the prereferral process. The section of findings includes each theme, related categories, subcategories and quotations.

\subsection{Experiences and views about the identification phase}

It is seen that in the initial phase of identifying the students, the teachers generally considered more than one skill area. Accordingly, 11 of all the participants reported that they identified the students with special needs as they had different social and communication skills and behaviours. P1 said "I understand from their behaviours, ways of speaking and their reactions to their peers in class. Some of them prefer to be lonely. Also, their responses to the questions allow us to identify them."

Two of the teachers stated that they identified the students with special needs as they had different levels of understanding/perceptions/behaviours and academic skills. P10, one of the participants, said "Behavioural and academic skills actually develop in a way parallel to one another. This also reflects upon their games and on their relationships with their friends."

Among the teachers, two of them reported that they identified the students with special needs because they had different communication and motor skills. In relation to this, P12 said, "I ask them several questions and pay special attention to their general status, their postures and psychomotor skills. Their responses to my questions are very important for me because these answers help me identify these students." Two of the students stated that they identified the students with special needs as they had different social, communication and academic skills.

In relation to this, $P 6:$ "... I say so considering my students who have special needs. They have communication problems, and they have difficulty in establishing eye-contact and expressing themselves. Most importantly, I repeatedly teach the same subject again and again, and I thus fail to start teaching the next subject."

In relation to the second theme, the things primarily done by the teachers, it was seen that in the process of identifying the students with special needs, six of the teachers stated that they tried to know more about the students and took care of them personally. P5 said "First, I establish a close relationship with the student or interact with him/her personally in different environments. In this way, I myself try to know more about the student." Three of the teachers stated that they tried to know more about the student and met/talked to his/her parents/family. P6 said,"... Later, during the break time, or in physical training lessons, I contact with the child, and when I feel that there is something special with the child, I talk to his/her family."

Three of the teachers reported that in the process of identifying the students with special needs, they first met/talked to his/her family, while three of the teachers said they cooperated with the advisory teacher. In relation to meeting the family, P12 said "I want to talk to the family first. I try to learn about the childhood of the student, his/her father and mother, the pregnancy period of the mother and about the general situation of the family. I mean I first ask questions to the family." In relation to cooperation with the advisory teacher, P1 said "We have the child see the advisory teacher because we don't have the necessary knowledge 
and experience. Our advisory teachers have more experience. If they consider it necessary, they send the child to the hospital."

\subsection{Experiences and views about the instructional adaptations in the pre-referral phase}

As the teachers' views about the instructional adaptations in the pre-referral process, five teachers stated that they assessed their students in the risk group via observations in the pre-referral process. P9 said "First, as I said before, I do observations. I watch his/her behaviours. I mean without using anything like a scale, I do assessments via my observations because most of the time, we are already together and because there are not many registered students in our class." Four of the teachers reported that besides observation, they did assessments based on the curriculum.

P10: "Mostly, we observe them. They already spend about four or five hours with us in a day. We also look at their performances in other courses. Not just in courses related to teaching how to read and write in Turkish, we observe them in other courses as well. Do they join the games? I mean is it a general failure? Or is it just specific to reading-writing? I first try to determine this."

Three of the teachers stated that while assessing the students they considered to have special needs, they not only did observations but also used assessment forms they obtained via the Internet or from rehabilitation centers, hospitals and other places like these. P6 reported his/her experiences as follows:

P6: "I search different websites on the Internet, of course, we are not expert. I mean we don't know whether it was mild, or whether it was a special learning disability. There are a few tests, and I try to use these tests. But generally, what we do for the child as an elementary school teacher is to observe him/her, to observe his/her interest in the lesson, and to see how much s/he can concentrate on the lesson. Through individual speeches, I do observations. This is actually the most effective method we can use."

Three of the teachers stated that they did not do any assessments. P14 said "I do not do any assessment, but if the child does not remember what he or she has learned or if he or she fails to learn, then I think s/he has a problem." In relation to the findings regarding the teachers' organizing the environment for their students in the risk group, 10 teachers stated that they preferred to have these students sit in the front or to do a U-shape seating arrangement. P2 said "I always made that student sit in the front of the classroom, near me. In this way, I had the opportunity to establish eye-contact with them. If the child is tall, then I make him or her sit in the front again and on the right side near the window. I mean they always sit in the front desks."

Five of the teachers reported that they did various environmental organizations for the whole class such as activity corners, visuals on walls and group works. These teachers also stated that they did special environmental arrangements in class for the students that they considered to have special needs. In relation to this, P5 mentioned his/her experiences as follows: "I always do changes in my class. I change the seating places of all the students. Also, during the group works, I create a U-shape or V-shape seating in class." In addition, two of these teachers stated that they made no U-shape or any other seating plans as they thought such seating might lead to discrimination. P12 reported his/her 
experiences as follows: "I can have them do group work but I wouldn't make a special seating plan for that student not to make him/her feel discriminated." Regarding the material adaptation in the pre-referral process, nine of the teachers stated that they preferred to use visual and concrete/tactile materials present for students in class. P11 reported his/her views as follows:

P11: “...To tell the truth, I didn't do anything special or extra for him/her, but I tried to use concrete materials that I can find in class environment. Actually, I had to do so because, otherwise, we wouldn't be able to go ahead."

Four teachers stated that they used course books and storybooks appropriate to the child's level. P14 said "For example, if that student is in $2^{\text {nd }}$ grade class but lacks the knowledge for that grade, I may sometimes use $1^{\text {st }}$ grade books..." Two of the teachers reported that they did not use a special material, saying,

P2: "To be honest, it is really difficult to deal individually with such students in a class of 34 or 35 students, but if it is math, or in any other course, we try to make use of whatever we have in hand for them. It wouldn't be true if I say that we allocate enough special time for such students."

In relation to the use of a special method, 13 teachers stated that they used various methods for the whole class like learning by doing/living, question-and-answer and acting/drama. However, the teachers reported that they did not use any special teaching method for the children in the risk group and that instead, they tried to apply the whole-class methods individually to these students. P4 said "While teaching in class, I don't pay special attention to that student. I personally deal with him/her out of class hours because other students waste time if I try to teach that student personally in class hours. Therefore, during break times, I teach that student more easily by simplifying the subject for him/her."

Two of the participants stated that they used special methods regarding the constraints experienced by the students. P6 reported his/her experiences related to an alternative method as follows "You know, when we were undergraduate students at university, we were taught an alternative method (called BASARA in Turkish) that can be applied to special education students. The teachers participating in the study were asked how they assigned the worksheets and homework to the students in the risk group within the scope of the instructional adaptations. Of all the teachers, 12 of them stated that they assigned simplified worksheets and homework appropriate to the students' levels.

P11: “... I gave him/her different things. I mean, for example, I am teaching 'multiplication' to the $3^{\text {rd }}$ grade students, while I am teaching 'addition' to that student. Therefore, I gave that student a worksheet and homework related to addition not multiplication."

Three of the teachers reported that they did not do a special arrangement for the students with special needs and that they assigned the same worksheets and homework to all the students including those with special needs.

P2: "S/he had a language speech disorder. S/he was very good at math. When I give them a worksheet in class, s/he was always the first to take it. We tried not to discriminate him/her from the others, but he got worried when he failed to do the worksheets or homework. At that time, we dealt personally with that student, and we tried to encourage him/her and worked together." 
It is seen that the teachers applied different methods to decrease the students' problem behaviours. Most of the teachers stated that they established close relationships with the student by touching him/her or by talking to him/her about his/her problem behaviour. P15 said "I have such students sit in a front desk due to their problem behaviours. For example, there was a student with a mild level of intellectual disability. Touching and holding his hands..."

Some of the teachers stated that they applied additional techniques such as presenting reinforcers, taking out of class, determining classroom rules, participating in fewer activities, giving homework and giving responsibility.

P6: "I had a student who always stood up in class. It was a combined class, and I had two inclusive students I made one of them the class president. I told him 'When I am out of class, you are the class president'. I gave him a responsibility, and he made his friends sit in silence in class..."

One teacher reported that in the case of problem behaviour, they gave the student time and waited for the end of the problem behaviour. P11 said "When he demonstrated a behaviour that I disliked, I didn't warn him in front of his friends. I took him out of class for a few minutes, but I didn't ask him to do this directly..."

In addition, one teacher stated that they used one of the punishment methods or more than one together.

P10: "We generally warn them. If there was no change in their behaviour despite our warning, we gave them little punishments. For example, standing on one foot, or doing something during break time. It is better to make them feel they are not different from the other students in class and they are part of the class. Otherwise, they may abuse it."

\subsection{General experiences and views about the pre-referral process}

In relation to teachers' experiences and views about pre-referral process, eight of the teachers stated that they made use of in-class observations to monitor the development of the students they considered to have special needs. P9 said "As I said before, I do observations. In this way, I learn about what they did everyday or what happened that day. I observe them by talking to them every day because communication is important." Three of the teachers stated that they monitored their students' development considering the curriculum and/or their academic skills. P3 said "I observe their reading skills by having them read. I also look at their writing because such students have problems in writing as well as in reading." Two of the teachers stated that they took notes about the student. P1 said "I always took notes, but I had a little bit difficulty in the scales. I took notes in my notebook to monitor them better."

In addition, one of the teachers, P12, stated that s/he used special scales, saying "We had scales for what we did. After the assessment of the student with these scales, we learned whether he learned the subject or not. I absolutely assess that student." P15 stated that they monitored their students' development via general in-class assessments, saying "These students are not successful in class as we can already learn via our assessments before the diagnosis."

The teachers were asked what they did to make the relationship positive between the students they considered to have special needs and the students who demonstrated 
normal development. Seven of the teachers reported that they talked in class to inform the children with normal development about the students with special needs. P3 said "Generally, I can talk to his friends when he is not with us. Of course, I speak without humiliating the student, just to inform the other students, and they generally listen to me carefully. "Seven of the participants stated that they carried out group games and activities. P7 said "In our last lessons in a day, we generally do free-time activities. Sometimes, we play games in class, and sometimes, I involve that student in the games we play in the school garden. "One of the participants, P15 stated that s/he became a model to develop positive relationships between the students, saying "In order to help him develop positive relationships with his friends, first, I have to behave that child positively because children take me as an example."

When the teachers were asked to state their views about cooperation with the other teachers at school in the pre-referral process, P7 stated that s/he did not cooperate with the other teachers at school, saying "Actually, he doesn't talk to his friends at all (...) and I didn't do anything like that." Among all the teachers, 14 of them reported that they should cooperate and did so with the other teachers for such purposes as counselling, information exchange and/or material support. P11 reported "When I met that student for the first time, I talked to his previous teacher. In this way, I tried to learn more about the student. Also, I cooperated with the other teachers..."

All the teachers stated that there was no special team for the pre-referral process at schools. In addition, 13 of the participants reported that they did not prepare a written, comprehensive and systematic intervention plan. P12 said "Though not officially, I make a monthly plan of what I want to do in class. I think about the activities I will do, I prepare the related documents." Among the teachers, P6 stated that they prepared a written but not comprehensive or systematic plan in the pre-referral process, saying "I made a rough plan in my mind. It was actually a written plan but not a long one like IEP..."

When the teachers were asked what they thought about family involvement in the pre-referral process, all the participants said they found it important. In addition, in relation to involvement of the families, 12 of the teachers stated that they interviewed the families either on face-to-face basis or on the phone to inform them. Among these teachers, P2 reported his/her experiences as follows:

P2: "We talk to them personally. We tell them what to do at home. For example, we tell them to read a book and allocate time to their child. Also, we tell them what to do for the course of mathematics."

Two of the participants stated that they themselves as well as the school staff held interviews with the parents to involve them in the process and that they made home visits. P11 said "Believe me, I even visited the family during lunch time and invited them to school, too. Also, I talked to them on the phone, and I talked to them face to face again and again. Also, I even wanted the child to be examined to see whether s/he was a gifted person or not..."

Among the teachers, P6 stated that s/he not only interviewed the family to involve them in the process but also invited them to participate in in-class activities, saying "We first hold a preliminary interview with the family to involve them in the process. If they show objection, I invite them to class as a guest." 
The teachers reported that in the process of referring their students to GRC, they talked to the family, applied to the advisory teacher, filled in a form related to the students' skills and talked to the school administration and other teachers. It was seen that most of the teachers first got support from the school advisory teacher and then preferred to do the things later. P2 described the process as follows "Before sending the student to GRC, we first contact the advisory teacher. Later, we talk to his parents; they talk to our advisory teacher..." Some of the teachers stated that they referred the student after talking to the family. In relation to this, P14 said "If the family is conscious, I mean if they will take the child and get him examined for diagnosis, I inform the family and put the responsibility on them."

Most of the teachers reported that they filled in a form for their students in the pre-referral process. When the participants were asked to state their views about the content and source of the form, it was seen that there was no scientific basis of the forms. P10:"There is a form, which GRC sends to special education institutions and which is a questionnaire we can find on the Internet as well. Actually, it is not a questionnaire but a form where we can write down our thoughts about the child."

\section{Discussion and Suggestions}

In the present study, the purpose was to determine the teachers' experiences and the adaptations they carried out for their students in the risk group in the pre-referral process. In line with the teachers' views, three themes were obtained: (a) teachers' experiences and views about the identification phase, (b) their experiences and views about the instructional adaptations done in the pre-referral process and (c) general experiences and views about the pre-referral process. In the light of the findings obtained in the study, it was seen that most of the teachers did observation in the initial phase of identifying the student in the pre-referral process, cooperated with the other teachers (Ugurlu and Kayhan, 2018) and did not prepare a written intervention plan (Tunc, 2011). The teachers reported that in the identification process the students they considered to have special needs, they tried to know more about them by establishing personal contact with them and talked to the families and/or to the advisory teacher (Cuhadar, 2017).In one study conducted with preschool teachers, Aydogdu et al. (2016) found that most of the teachers did not attempt to do anything after the initial phase of identifying the student. In addition, the researchers reported that adaptation problems and inefficacies in communicative and social skills were prominent in the initial identification phase. Similarly, in the present study, the teachers thought that the students who differed from their peers in social, communicative, academic and behavioural respects were in the risk group. In other similar studies, it was revealed that the teachers considered their students to be in the risk group due to their social, academic and behavioural differences (Dunn, 2006; Gottlieb and Weinberg, 1999; Shepard, Smith and Vojir, 1983; van der Veen, Smeets and Derriks, 2010) and that the teachers initiated a special process for these students (Del'Holme et al., 1996; Shepard, Smith and Vojir, 1983; Tunc, 2011). Failure to read as an academic skill (Lane, Pierson, Robertson and Little, 2004) and failure to maintain 
attention during an activity (Dunn, Cole and Estrada, 2009) were considered by the teachers to be potentially important for the pre-referral process (Young and Gaughan, 2010). The reason why academic skills were prominent could be the fact that they mostly studied these skills (Del'Homme, Kasari, Forness and Bagley, 1996). In literature, there are a number of studies investigating whether such factors as gender, ethnic origin, families' socio-economic status, teacher's professional experience, teacher's knowledge of individual differences, number of students in class, the time for the assessment process and ambiguous or unclear laws have influence on teachers' referral of their students to the diagnosis process (Christenson, Ysseldyke, Jen Wang and Aegozzine, 1983; Lane, Pierson, Robertson and Little, 2004); however, it is not certain yet whether these factors have any influence on the referral process (Del'Homme, Kasari, Forness and Bagley, 1996).

Doing instructional adaptations is important for decreasing the number of students in the referral process (Nevin, 1986). Considering the theme of experiences regarding the instructional adaptations in the present study, it could be stated that the teachers primarily made use of observation (Tunc, 2011) and curriculum-based assessment as a tool for evaluation. It is seen that in the initial identification phase, curriculum-based assessments are used as the main evaluation tool (Weishaar, Weishaar and Budt, 2002). When instructional adaptations are examined within the scope of environment, method and material, it is seen that teachers organize a special environment for their students and give more importance to tactual and visual materials (Tunc, 2011) and that they differ in terms of method, though. In one study, McLeskey and Wladron (2002) reported that the teachers did not customize their methods in inclusive education and that they did not find it appropriate to discriminate students. In the present study, instead of presenting a different method (Harrington and Gibson, 1986), the teachers applied the same method personally (Akalın, 2015; Esmer et al., 2017) and simplified the worksheets (Cuhadar, 2017). In related literature, it is reported that for their students they consider or know to have special needs, teachers make use of similar methods such as organizing the environment in instructional processes (Cuhadar, 2017; Y1ld1z-Güner, 2015; Yıldız-Güner and Sazak-Pınar, 2012; Harrington and Gibson, 1986; Tunc, 2011; Vural and Y1kmis, 2008), applying methods on-one-one basis (Fuchs Fuchs and Bishop, 1992), simplifying the materials (Onder, 2007; Sarac and Colak, 2012; Vural and Y1kmiş, 2008) and assigning additional worksheets (Tunc, 2011). It is also seen that teachers apply instructional adaptations in educational environments and that due to inefficient adaptations, there is a need for information support (Akalın 2015; Lane Mahdavi and Borthwick-Duffy, 2003; Vural and Yikmis, 2008).

In addition, teachers also experience problems because of their lack of knowledge about in-class problem behaviours besides instructional adaptations (Akalın, 2015; Güner, 2011). In the present study, the teachers frequently established close relationships with the students regarding their problem behaviours and that in inclusive environments, the teachers applied various class management techniques (Akalın, 2015; Ceylan and Y1kmis, 2017) to deal with problem behaviours (Ceylan and Y1kmis, 2017; Harrington and Gibson, 1986) such as determining classroom rules, taking out of 
classroom, presenting reinforces, giving responsibility (Akalın, 2015) and warning (Tunc, 2011). Informing teachers about practices for determining and diminishing the function of problem behaviours is necessary and important for effective application of interventions in the pre-referral process. Students' in-class problem behaviours and academic achievements have influence on their relationships with their peers. Informing peers about the pre-referral process regarding a student who fails to learn in the same pace with their peers and/or who demonstrate inappropriate behaviours will contribute positively to the process. In the present study, the teachers informed the peers, established interaction via group games and became a model.

Monitoring the practices and adaptations carried out in the pre-referral process and assessing them all objectively determine whether to initiate the next detailed assessment-diagnosis process. In the present study, the teachers more frequently preferred to use the observation method for the evaluation of the process (Cuhadar, 2017). Observation is an inevitable information evaluation technique for assessments in the pre-referral process, while observations without any observation form or planning in instructional environments will lead to doubts in terms of objectivity. Permanent product records gathered about the student via observations are fairly valuable. However, it was seen that only two of the teachers kept a special record for their students. Systematic data collected in certain intervals via more than one assessment technique are important for objective evaluation and thus for an appropriate and correct referral (Weishaar, Weishaar and Budt, 2002).

Most teachers do observations and adaptations regarding the students they consider to have special needs, yet they avoid preparing and applying a written intervention plan (Cuhadar, 2017). In other studies, in literature, teachers report that there is no governmental obligation and that it is difficult to prepare, apply and evaluate a written intervention plan. When the international literature is examined, it is seen that there are cooperative teams for the pre-referral process in many states despite the lack of a governmental practice. Studies demonstrate a decrease in the number of students referred to the diagnosis process at schools where there are pre-referral process teams. In addition, studies point to the importance of teamwork and cooperation. The teachers participating in the present study emphasized the importance of cooperation and stated that they cooperated with the other teachers. The teachers also reported that they applied to the advisory teacher for their students (Sarac and Colak, 2012), did observations and evaluations together with the advisory teacher regarding both the students and their families and tried to provide additional support with the pre-service teachers (Akalın, 2014). Supporting teachers' cooperation and making this cooperation more systematic in the pre-referral process increase teachers' efficacies and decrease the stress levels related to the process (Lhospital and Gregory, 2009). Pre-referral teams formed on the basis of cooperation allow students to be assessed by more than one expert, allow doing adaptations for students in line with the experts' evaluations, and allow these students to continue their education together with their peers in the same class with the help of the systematic application of the adaptations. 
The findings obtained in the present study demonstrate that the pre-referral process was limited to the adaptations which were not systematic and which the teachers applied based on their own efforts. Informing teachers about the pre-referral process and about what to do in this process will not only help decrease the number of students involved in the referral process by increasing the in-class adaptations but also allow keeping the students in the same class who will be able to continue their education with their peers with the help of in-class interventions. In addition, forming pre-referral process teams at schools will allow the teacher to cooperate with the other teachers in the referral process, which will in turn help that teacher do correct evaluations and necessary adaptations. According to the international literature, it is necessary to carry out systematic applications such as early intervention and response to the intervention in the pre-referral process. In our country, making such similar systematic applications a legal necessity and putting these applications into force will be an important step in the process. Future studies could examine the factors influential on teachers' attitudes towards the referral process within the context of educational environments in our country. Moreover, studies could be conducted to investigate the effectiveness of prereferral process teams.

\section{About the Author(s)}

Mine Kizir, PhD, is an assistant professor in Special Education Department at Muğla S1tkı Koçman University, Turkey. Her research areas are autism spectrum disorders, family education, imitation skills education, and early intervention. Her Orcid is orcid.org/0000-0001-8801-5693.

Candan Hasret Şahin, PhD, is an assistant professor in Special Education Department at Muğla Sitkı Koçman University, Turkey. Her research areas are autism spectrum disorders, family education, safety skills, and inclusion. Her Orcid is orcid.org/0000-00022414-1874.

\section{References}

Akalın, S. (2015). Kaynaştırma sınıfı öğretmenlerinin sınıf yönetimine ilişkin görüşleri ve gereksinimleri. Ankara Üniversitesi Ĕ̆itim Bilimleri Fakültesi Özel Ĕ̆itim Dergisi, 16(03), 215-236.

Akalın, S. (2014). Okul Öncesi Eğitim Kurumlarında Çalışan Rehber Öğretmenlerin Kaynaştırma Uygulamalarına İlişkin Gereksinimleri. International Journal of Early Childhood Special Education, 6(1).

Aydoğdu, F., Akalın, A., Polat, B., İrice, N., \& Akpınar, M. (2016). Okulöncesi Öğretmenlerin Özel Gereksinimli Çocukların Tanılanması Konusundaki Görüşlerinin İncelenmesi. Manas Sosyal Araştırmalar Dergisi, 5(4), 13-21.

Bozkurt, F. (2009). Zihinsel yetersiz tanısı alan çocukların tanılama süreçlerinin betimlenmesi. Yayımlanmamış Doktora Tezi. Anadolu Üniversitesi, Eskişehir. 
Buck, G. H., Polloway, E. A., Smith-Thomas, A., \& Cook, K. W. (2003). Prereferral intervention processes: A survey of state practices. Exceptional Children, 69(3), 349360.

Carter, J., \& Sugai, G. (1989). Survey on prereferral practices: Responses from state departments of education. Exceptional Children, 55(4), 298-302.

Ceylan, F., \& Yıkmıs, A. (2017). Kaynaştırma öğrencilerinin sergilediği problem davranışlara yönelik sınıf öğretmenlerinin uyguladıkları önleme ve müdahale stratejileri. Uludă̆ Üniversitesi Ĕ̆itim Fakültesi Dergisi, 30(1), 239-264.

Christenson, S., Ysseldyke, J. E., Jen Wang, J., \& Aegozzine, B. (1983). Teachers' attributions for problems that result in referral for psychoeducational evaluation. The Journal of Educational Research, 76(3), 174-180.

Cuhadar, S. (2017). Sınıf öğretmenlerinin eğitsel değerlendirme sürecine ilişkin görüşleri. Trakya Üniversitesi Ĕ̆itim Fakültesi Dergisi, 7(2), 526-549.

Del'Homme, M., Kasari, C., Forness, S. R., \& Bagley, R. (1996). Prereferral intervention and students at-risk for emotional or behavioral disorders. Education and Treatment of Children, 272-285.

Dunn, M. W. (2006). It Was Written All Over Him: Classroom Teachers' Referral Criteria for Special Education Services. International Journal of Special Education, 21(2), 124139.

Dunn, M. W., Cole, C. M., \& Estrada, A. (2009). Referral criteria for special education: General education teachers' perspectives in Canada and the United States of America. Rural Special Education Quarterly, 28(1), 28-37.

Esmer, B., Yılmaz, E., Güneş, A. M., Tarım, K., \& Delican, B. (2017). Sınıf öğretmenlerinin kaynaştırma öğrencilerinin eğitimine ilişkin deneyimleri. Kastamonu Ĕ̆itim Dergisi, 25(4), 1601-1618.

Fuchs, L. S., Fuchs, D., \& Bishop, N. (1992). Instructional adaptation for students at risk. The Journal of Educational Research, 86(2), 70-84.

Fuchs, D., Fuchs, L. S., Bahr, M. W., Fernstrom, P., \& Stecker, P. M. (1990). Prereferral intervention: A prescriptive approach. Exceptional Children, 56(6), 493-513.

García, S. B., \& Ortiz, A. A. (2006). Preventing disproportionate representation: Culturally and linguistically responsive prereferral interventions. Teaching Exceptional Children, 38(4), 64-68.

Good, K. I. (2004). The experiences of parents with the pre-referral process: An evolutionary perspective. Doktora Tezi. Texas Tech University, ABD.

Gottlieb, J., \& Weinberg, S. (1999). Comparison of students referred and not referred for special education. The Elementary School Journal, 99(3), 187-199.

Graden, J. L. (1989). Redefining "prereferral" intervention as intervention assistance: Collaboration between general and special education. Exceptional Children, 56(3), 227-231.

Graden, J. L., Gasey, A., \& Bonstrom, O. (1983). Pre-re/errai Jnlerveniions; Effects on referral rates and teacher attitudes (Research Report No: 140J. Minneapolis. MN: Institute for Research on Learning Disabilities. 
Graden, J. L., Casey, A., \& Christenson, S. L. (1985). Implementing a prereferral intervention system: Part I. The model. Exceptional children, 51(5), 377-384.

Gürsel, O. veVuran, S. (2015). Değerlendirme ve Bireyselleştirilmiş Eğitim Programlarını Geliştirme. İ. H. Diken (Ed.) Illköğretimde Kaynaştırma. Ankara: Pegem Akademi Yayıncilık.

Hammond, H., \& Ingalls, L. (1999). Maintaining school-based prereferral teams: An eight year study. Rural Special Education Quarterly, 18(2), 17-21.

Harrington, R. G., \& Gibson, E. (1986). Preassessment procedures for learning disabled children: Are they effective?. Journal of Learning Disabilities, 19(9), 538-541.

Henderson, J. L. (2008). Disproportionality in special education: The relationship between prereferral intervention teams and the special education process. Doktora Tezi. George State University, ABD.

Jennings, M. (2008). Before the special education referral: Leading intervention teams. Corwin Press.

Kargın, T. (2007). Eğitsel değerlendirme ve bireyselleştirilmiş eğitim programı hazırlama süreci. Ankara Üniversitesi Eğitim Bilimleri Fakültesi Özel Ĕ̆itim Dergisi, 8(01), 1-15.

Lane, K. L., Mahdavi, J. N., \& Borthwick-Duffy, S. (2003). Teacher perceptions of the prereferral intervention process: A call for assistance with school-based interventions. Preventing School Failure: Alternative Education for Children and Youth, 47(4), 148-155.

Lane, K. L., Pierson, M. R., Robertson, E. J., \& Little, A. (2004). Teachers' views of prereferral interventions: Perceptions of and recommendations for implementation support. Education and Treatment of Children, 420-439.

Laverty, J. R. (2007). A study of the prereferral intervention process in Pennsylvania following the rescinding of the Instructional Support Team mandate. Doktora Tezi. Indiana University of Pennsylvania, ABD.

Lee-Tarver, A. (2006). A survey of teachers' perceptions of the function and purpose of student support teams. Education, 126(3), 525-534.

Lhospital, A. S., \& Gregory, A. (2009). Changes in teacher stress through participation in pre-referral intervention teams. Psychology in the Schools, 46(10), 1098-1112.

McLeskey, J., \& Waldron, N. L. (2002). Inclusion and school change: Teacher perceptions regarding curricular and instructional adaptations. Teacher education and special education, 25(1), 41-54.

Milli Eğitim Bakanlığı [MEB] (2018). Özel Eğitim Hizmetleri Yönetmeliği. 07.07.2018. 30471 Sayılı Resmi Gazete. https://orgm.meb.gov.tr/www/ozel-egitim-hizmetleriyonetmeligi-yayimlandi/icerik/1089 adresinden 20.01.2020 tarihinde edinilmiştir.

Miles, M. B., \& Huberman, A. M. (1994). Qualitative data analysis: An expanded sourcebook (2nd ed.). Thousand Oaks, CA, US: Sage Publications.

Newell, M. M. (2018). Relationship between Teachers' Sense of Efficacy and Student Referrals to the Intervention Support Team. Doktora Tezi. University of Phoenix, ABD. 
Noll, M. B., Kamps, D., \& Seaborn, C. F. (1993). Prereferral intervention for students with emotional or behavioral risks: Use of a behavioral consultation model. Journal of Emotional and Behavioral Disorders, 1(4), 203-214.

Onder, M. (2007). Sınıf Öğretmenlerinin Zihin Engelli Kaynaştırma Öğrencileri İçin Sınıf İçindeYaptıkları Öğretimsel Uygulamaların Belirlenmesi. Yayınlanmamış Yüksek Lisans tezi, Abant İzzetBaysal Üniversitesi, Bolu.

Pugach, M. C., \& Johnson, L. J. (1989). Prereferral interventions: Progress, problems, and challenges. Exceptional Children, 56(3), 217-226.

Reynolds, M. C., \& Balow, B. (1972). Categories and variables in special education. Exceptional Children, 38(5), 357-366.

Safran, S. P., \& Safran, J. S. (1997). Prereferral consultation and intervention assistance teams revisited: Some new food for thought. Journal of Educational and Psychological Consultation, 8(1), 93-100.

Safran, S. P., \& Safran, J. S. (1996). Intervention assistance programs and prereferral teams: Directions for the twenty-first century. Remedial and Special Education, 17(6), 363-369.

Salvia, J., Ysseldyke, J., \& Bolt, S. (2010). Assessment: In special and inclusive education. Wadsworth Cengage Learning. Belmont, USA.

Sarac, T., \& Colak, A. (2012). Kaynaştırma uygulamaları sürecinde ilköğretim sınıf öğretmenlerinin karşılaştıkları sorunlara ilişkin görüş ve önerileri. Mersin Üniversitesi Ĕ̆itim Fakültesi Dergisi, 8(1).

Shepard, L. A., Smith, M. L., \& Vojir, C. P. (1983). Characteristics of pupils identified as learning disabled. American Educational Research Journal, 20(3), 309-331.

Sindelar, P. T., Griffin, C. C., Smith, S. W., \& Watanabe, A. K. (1992). Prereferral intervention: Encouraging notes on preliminary findings. The Elementary School Journal, 92(3), 245-259.

Slonski-Fowler, K. E., \& Truscott, S. D. (2004). General education teachers' perceptions of the prereferral intervention team process. Journal of educational and psychological consultation, 15(1), 1-39.

Swain, K. D., \& Hagaman, J. L. (2020). Elementary special education teachers' use of CBM data: A 20-year follow-up. Preventing School Failure: Alternative Education for Children and Youth, 64(1), 48-54.

Swank, B. J. (2017). Teacher Perceptions of Their School's Pre-Referral Intervention Team Program: A Mixed-Methods Study (Doctoral dissertation, Delaware Valley University).

Tunc, Z. (2011). Sınıf öğretmenlerinin risk taşıyan öğrenciler için gönderme öncesi sürece ilişkin görüşleri. Yayımlanmamış Yüksek Lisans Tezi. Marmara Üniversitesi, İstanbul.

Turnbull, M. (2019). Subjectivity Within the Pre-Referral Intervention Process: The Difference Between Academic and Behavioral Interventions in an Urban Elementary School. Yayımlanmamış Doktora Tezi. University of Minnesota, ABD. 
Uğurlu, N. I., \& Kayhan, N. (2018). Sinıf öğretmenlerinin özel gereksinimli öğrencilerin eğitsel değerlendirme süreçlerine yönelik görüşlerinin incelenmesi. Adıyaman Üniversitesi Sosyal Bilimler Enstitüsü Dergisi, (29), 626-669.

van der Veen, I., Smeets, E., \& Derriks, M. (2010). Children with special educational needs in the Netherlands: Number, characteristics and school career. Educational Research, 52(1), 15-43.

Vural, M., \& Yıkmıs, A. (2008). Kaynaştırma sınıfı öğretmenlerinin öğretimin uyarlanmasına ilişkin yaptıkları çalışmaların belirlenmesi. Abant İzzet Baysal Üniversitesi Ĕ̆itim Fakültesi Dergisi, 8(2).

Yetter, G. (2010). Assessing the acceptability of problem-solving procedures by school teams: preliminary development of the pre-referral intervention team inventory. Journal of Educational and Psychological Consultation, 20(2), 139-168.

Yild1z, N. G. (2015). Teacher and Student Behaviors in Inclusive Classrooms. Educational Sciences: Theory and Practice, 15(1), 177-184.

Yıldız, N. G., \& Pınar, E. S. (2012). Kaynaştırma Sınıflarındaki Özel Gereksinimli Öğrencilere Yöneltilen Öğretmen Davranışlarının İncelenmesi. International Online Journal of Educational Sciences, 4(2).

Yıldırım, A., \& Şimşek, H. (2008). Sosyal bilimlerde nitel araştırma yöntemleri (6th Ed). Ankara: Seçkin Yayıncılık.

Young, H. L., \& Gaughan, E. (2010). A multiple method longitudinal investigation of prereferral intervention team functioning: Four years in rural schools. Journal of Educational and Psychological Consultation, 20(2), 106-138.

Ysseldyke, J. E., Vanderwood, M. L., \& Shriner, J. (1997). Changes over the past decade in special education referral to placement probability: An incredibly reliable practice. Diagnostique, 23(1), 193-201.

Weishaar, M. K., Weishaar, P. M., \& Budt, C. (2002). Prereferral intervention: Problemsolving method and curriculum-based measurement. Rural Special Education Quarterly, 21(3), 3-9.

Will, M. C. (1986). Educating children with learning problems: A shared responsibility. Exceptional children, 52(5), 411-415. 
Mine Kizir, Candan Hasret Şahin

ELEMENTARY SCHOOL TEACHERS' EXPERIENCES REGARDING THE PREREFERRAL PROCESS

Creative Commons licensing terms

Authors will retain the copyright of their published articles agreeing that a Creative Commons Attribution 4.0 International License (CC BY 4.0) terms will be applied to their work. Under the terms of this license, no permission is required from the author(s) or publisher for members of the community to copy, distribute, transmit or adapt the article content, providing a proper, prominent and unambiguous attribution to the authors in a manner that makes clear that the materials are being reused under permission of a Creative Commons License. Views, opinions and conclusions expressed in this research article are views, opinions and conclusions of the author(s). Open Access Publishing Group and European Journal of Special Education Research shall not be responsible or answerable for any loss, damage or liability caused in relation to/arising out of conflict of interests, copyright violations and inappropriate or inaccurate use of any kind content related or integrated on the research work. All the published works are meeting the Open Access Publishing requirements and can be freely accessed, shared, modified, distributed and used in educational, commercial and non-commercial purposes under a Creative Commons Attribution 4.0 International License (CC BY 4.0). 